\title{
Emotional Stability among Annamalai University Students
}

\author{
Mohammad Amin Wani ${ }^{1 *}$, Dr. R. Sankar ${ }^{2}$, J. Angel ${ }^{3}$, P. Dhivya ${ }^{4}$, \\ S. Rajeswari ${ }^{5}$, K. Athirai ${ }^{6}$
}

\section{ABSTRACT}

The cardinal object of the present study was to find the level of emotional stability among Annamalai University students in Tamil Nadu. The sample of present study consists of 300 students divided in two equal groups 150 boys and 150 girl students in each group 75 students was from general category and 75 was from SC category. The data was collected with the help of emotional stability test developed by A. S. Gupta and A.K. Singh. Results revealed that there is no significant difference found between mean scores of emotional stability of boys and girls also the mean scores of emotional stability of students belongs to General and SC category. Further findings also suggested that boys are more emotionally stable than girl's also general category students are more emotionally stable the SC category students.

Keywords: Adolescents, Emotional Stability, Gender, Locality, Parent Child Relationship

The term "Emotion" is derived from the Latin word "Emotes" which means "to movere", "to move" or "to put in motion". In psychology the word "Emotion" is used to describe a state of excitement in the organism. Emotion is complex set of interactions among subjective and objective factors, medicated by neural hormonal system, which can give rise to affective experience such as feelings of arousal, pleasure, displeasure; generate cognitive process such as emotionally relevant perceptual effects, appraisals, labeling processes; activate widespread physiological adjustments to the arousing conditions and lead to behaviour that is often, but not always expressive, goal directed, and adaptive.

\footnotetext{
${ }^{1}$ Ph.D Research scholar in Psychology Annamalai University Tamil Nadu, India

${ }^{2}$ Assistant Professor Department of Psychology Annamalai University Tamil Nadu, India

${ }^{3}$ M. Sc Clinical Psychology Department of Psychology Annamalai University Tamil Nadu, India

${ }^{4}$ M. Sc Clinical Psychology Department of Psychology Annamalai University Tamil Nadu, India

${ }^{5}$ M. Sc Clinical Psychology Department of Psychology Annamalai University Tamil Nadu, India

${ }^{6}$ M. Sc Clinical Psychology Department of Psychology Annamalai University Tamil Nadu, India

*Responding Author

(C) 2016, A Wani, R Sankar, J Angel, P Dhivya, S Rajeswari, K Athiraj; licensee IJIP. This is an Open Access Research distributed under the terms of the Creative Commons Attribution License (http://creativecommons.org/licenses/by/2.0), which permits unrestricted use, distribution, and reproduction in any Medium, provided the original work is properly cited.
} 


\section{Emotional Stability among Annamalai University Students}

In fact an emotion has four major components (feeling state, cognitive processes, physiological change and associated behavior). Emotions are characterized by physiological arousal, change in facial expression, gestures, postures, and subjective feelings. The words used by people to describe their emotions typically show consistent patterns for example those who are unhappy reports feelings of sadness. Emotions have both physiological and cognitive elements that directly influence individual's behavior.

\section{Emotional Stability}

Emotions have an influential value in life, control on emotions is essential for prosperous life. A person who fails to control his or her emotions faces lot of problems in day to day life. Even emotional stability results happy and adjustable life therefore emotional stability is an important aspect of human life. Emotional stability is one of the seven important indicators of mental health (Matheen, 2011). Emotional stability is the process in which the personality is continuously striving for greater sense of emotional health, both intra-physically and intrapersonally (Smitson, 1974). Emotional stable individuals are calm and happy, they are satisfied with their life; they deal with the situation in perfect way and solve their problems easily.

In present days where people live with highly ambitious and competitive society to work hard for prosperous life they do lot for the betterment of life but on another side emotional pressure is increasing also in students who has a tough competition from their class till getting job, they lose their control over their emotions which results imbalanced and maladjusted personality. Because of their uncontrolled emotions their family suffers lot even they fail in making and maintaining relationships. Also our students who have no control on their emotions misbehave with their classmates, roommates, teachers etc. thus they became dangerous for the society. Thus emotional stability is essential for educational growth and development; teachers should taught students how to make control, maintain, and develop emotions as emotions are present in every activity and they are prime movers of thought and conduct. That is why researchers conduct huge number of researches to highlight the importance and various aspects of emotions. Here the investigator reviews few of them. Shaikh et al., (2016) found no significant difference between the levels of emotional stability among boys and girls. Zapata (2015) researched emotional stability and emotional maturity among students and found significant difference between levels of emotional stability and emotional maturity. Arora \& Kaur (2014) investigated emotional stability among 200 adolescents in relation to parent child relationship. They found no significant relationship between protecting, loving, object reward and neglecting dimensions of parent child relationship and emotional stability. Jasoria et al., (2014) revealed that neglecting parent child relationship significantly negatively correlated with emotional stability of the child $(p<0.01)$. Similarly emotional maturity showed negative correlation with indifferent parent child relationship ( $<<0.05)$ and neglecting parent child relationship ( $<<0.05)$. Renu \& Sharma (2014) investigate functioning of emotion and positive health among adults. They found significant relationship between the dimensions of positive health and dimensions of functioning of 


\section{Emotional Stability among Annamalai University Students}

emotions. Tarannum \& Khatoon (2009) uncovered that gender emerged as the significant predictor of emotional stability. Sharma (2006) assessed the emotional stability among students with visually disabled in relation to study habits. Results revealed that children with high emotional stability have better study habits than their counterparts with low emotional stability. Aleem (2005) examined emotional stability among college youth. Findings show that male students are more emotionally stable than female students. Qureshi et al., (1998) revealed that significant differences were found between undergraduate and postgraduate students in respect to emotional stability. Results also show insignificant differences between male and female leaders.

\section{Problem}

To assess the levels of emotional stability among university students

\section{Objectives}

1. To find the level of emotional stability among male and female students.

2. To find the level of emotional stability among general and SC category students.

\section{Hypotheses}

1. There would be significant differences in emotional stability of male and female students.

2. There would be significant differences in emotional stability of general and SC category students.

\section{METHODS}

\section{Sample}

The sample of the present study comprised of 300 students. Of these, there were 150 boys and 150 girl students in each group 75 students was from general category and 75 was from SC category.

\section{Tool}

For the measurement of emotional stability the investigator used emotional stability test developed by A. S. Gupta and A.K. Singh. The scale consists 15 items classified as positive and negative. Positive items are scored as 1 and negative item as 0 . But for item 9 and 10 the scoring method is reversed.

\section{Procedure}

In the present study all the students taken during data collection was approached individually. The investigator established proper rapport with each subject before administration of the test. A brief overview of the study was given than questionnaire was handover to the subject and was asked to read all the instructions carefully before giving the response, after 10 minutes the subject handover the questionnaire and were thanked by the investigator for their cooperation. Hence the data was collected. 


\section{RESULTS}

The present study mainly strived to investigate the levels of emotional stability among university students. For this purpose the data was collected from the students of Annamalai University. The obtained scores were assigned for different responses according to the item. Later these scores were arranged in tabular form than Mean and t- test was applied for statistical analysis. Results are given in tables.

Table-1, Showing mean, S.D, $S_{E} D$ and $t$ - value of boys and girls

\begin{tabular}{|l|l|l|l|l|l|l|l|}
\hline Group & Scores & No & Mean & SD & S $_{\mathbf{E}} \mathbf{D}$ & df & t- value \\
\hline Boys & 1312 & 150 & 8.74 & 9.11 & & & \\
\cline { 1 - 4 } Girls & 1259 & 150 & 8.39 & 8.82 & 1.02 & 298 & 0.34 \\
\hline
\end{tabular}

Table- 2, Showing mean, S.D, $S_{E} D$ and t- value of general and SC Category students

\begin{tabular}{|l|l|l|l|l|l|l|l|}
\hline Category & Scores & No & Mean & SD & S $\mathbf{E}$ & df & t- value \\
\hline General & 1288 & 150 & 8.58 & 9.00 & & & \\
\cline { 1 - 4 } SC & 1283 & 150 & 8.55 & 8.93 & 1.03 & 298 & 0.01 \\
\hline
\end{tabular}

\section{DISCUSSION}

The results of present study demonstrated that there is no significant difference found between mean scores of emotional stability of boys and girls also the mean scores of emotional stability of students belongs to General and SC category.

The mean and S.D value for emotional stability of boys and girls were found $[(\mathrm{M}=8.74$, $S . D=9.11),(M=8.39, S . D=8.82), S_{E} D=1.02$ ] and the obtained t- value (0.34) with df 298 is found less than tabulation value at 0.05 level of significance it rejects our first hypothesis. Our findings are supported by various previous studies conducted by researchers like Shaikh et al., (2016) and Qureshi et al., (1998). Similarly our second hypothesis is also rejected as the obtained t-vale (0.01) with df 298 is not significant at any level of significance. The mean, S.D and $S_{E} D$ value of general category and SC Category students was found [(M=8.58, S.D=9.00), $(M=8.55$, $\mathrm{S} . \mathrm{D}=8.93) \mathrm{S}_{\mathrm{E}} \mathrm{D}=1.03$ ] respectively.

While comparing the mean scores of boys with girls it was found that boys are slightly more emotionally stable than girls. Similarly students from general category are found slightly more emotionally stable the SC category students as mean scores of general category students is more than SC students. Therefore on the basis of the results found in the present study we may say that boys and general category students have more control on emotions than girls and SC category students. In other words we can say that boys and general category students have good adjustment abilities than girls and SC students. 


\section{Emotional Stability among Annamalai University Students}

\section{CONCLUSION}

To conclude the present study demonstrated that there is insignificant difference between emotional stability scores of boys and girls, General and SC category students. Same time boys are more emotionally stable than girls and also students from general category are more emotionally stable than SC category students.

\section{Acknowledgments}

The author appreciates all those who participated in the study and helped to facilitate the research process.

\section{Conflict of Interests}

The author declared no conflict of interests.

\section{REFERENCES}

Aleem, S. (2005). Emotional stability among college youth. Journal of the Indian Academy of Applied Psychology, Vol. 31, No.1-2, P: 100-102.

Arora, B., \& Kaur, J. (2014). Emotional stability among adolescents in relation to parent child relationship. The International Journal of Humanities \& Social Studies, Vol. 2, Issue 5, $P$ : 305-308.

Jasoria, A., Gupta, R., K., \& Singhvi, M. (2014). Parent child relationship predict emotional maturity among school going students. Indian Journal of Health and Well Being, Vol.5, Issue 11, $P$ : 1362-1364.

Matheen, W. (2011). Parent child relationship and emotional maturity of city college girls. Golden research thoughts, Vol. 1, Issue 1, P: 1-4.

Qureshi et al., (1998). Emotional stability among student leaders. Psycholingua, Vol. 28, P: 135-138.

Renu, \& Sharma, N (2014). Functioning of emotion and positive health: A co-relational study among adults. Journal of Indian Health Psychology, Vol. 9, No 1, P: 37-49.

Sharma, S. (2006). Emotional stability of visually disabled in relation to study habits. Journal of Indian Academy of Applied Psychology, Vol.32, Issue 1, P: 30-32.

Shaikh, P., Shaikh, A., \& Wahed, A. (2016). A study of emotional stability among children's. Scholars Research Journal for Humanity Science \& English Language, Vol. 3, Issue 15, $P$ : 3623-3627.

Tarannum, M. and Khatoon, N. (2009). Self esteem and emotional stability of visually challenged students. Journal of the Indian Academy of Applied Psychology, Vol. 35, Issue 2, $P: 245-266$.

Zapata, A. (2015). The emotional stability and emotional maturity of fourth year teacher education students of the Bulacan state university. Journal of Social Sciences \& Humanities Research, Vol.1, Issue 1, P: 1-5.

How to cite this article: A Wani, R Sankar, J Angel, P Dhivya, S Rajeswari, K Athiraj (2016), Emotional Stability among Annamalai University Students, International Journal of Indian Psychology, Volume 3, Issue 4, No. 66, ISSN 2348-5396 (e), ISSN: 2349-3429 (p), DIP:18.01.167/20160304, ISBN: 978-1-365-39396-9 